Slyvka, H. (2003) Imunokoryhuyuchyy vplyv protyzapal'noho preparatu izamben na klitynnyy imunitet sobak do ta pislya shcheplennya. Veterynarna medytsyna Ukrayiny, 2, 36-38 (in Ukrainian).

Allison, A. B., Kohler, D. J., Ortega, A., et al. (2014). Host-specific parvovirus evolution in nature is recapitulated by in vitro adaptation to different carnivore species. PLOS. Pathog, 11, 6-10.

Lund, E. M., et al. (1999). Health status and population characteristics of dogs and cats examined at private veterinary practices in the United States. Journal of the American Veterinary Medical Association, 214, 1336-1341.

Decario, N. et al. (2007). Molecular epidemiology of canine parvovirus Europe. Emerging infections disease,13, 12221224.

Mira, F, Dowgier, G, Purpari, G., et al. (2018). Molecular typing of a novel canine parvovirus type 2a mutant circulating in Italy. Infect Genet Evo.I, 18, 1567-1348.

\title{
RENGENOGRAPHY ROLE IN THE DIAGNOSIS OF THE DISEASES OF THE LOCOMOTOR APPARATUS IN THE HORSE (CLINICAL CIRCUMSTANCES)
}

\author{
D. Sarbash, K. Sinyagovskay \\ Kharkiv State Zooveterinary Academy, Kharkiv, Ukraine \\ Academichna str., 1, Mala Danylivka, Dergachi district, Kharkiv region, Ukraine, 62341
}

E-mail: max milos@ukr.net

The article presents the clinical case of the diagnosis of the disease of the locomotor apparatus in a horse according to clinical, ultrasound and $X$-ray studies. The given data testify that the implementation of radiography is one of the leading diagnostic methods and should be carried out in two projections (direct and lateral), which significantly increases the informativeness of the state of the morphostructure of the bones.

The material for the study was a stallion of darkskinny mascara, aged 4 years. For the diagnosis of diseases of locomotor apparatus horse used clinical studies, both in a state of rest, and when wiring in a circle. This type of diagnosis was carried out before and after novocaine perineural anesthesia of the tibialis ( $n$. peronaeus profundus) nerves.

Ultrasound studies of the tendon-binding apparatus, $X$-ray examination of all bones and joints of the distal part of the pelvic extremity, as well as X-ray of the knee joint, were performed.

The horse was purchased in 2016. The general condition was normal. Hold a horse in a separate batch. Every day the horse was in training. In unknown circumstances, after 2 months, the horse started limping on the right pelvic floor. The performed clinical, $X$-ray and ultrasound investigations revealed the presence of damage to the tendon-binding apparatus in the area of the bone marrow, inflammation of the intestinal muscle.

$X$-ray examination of phalanges of the fingers of the limbs and knee joints of lesions of the destruction or bone densification was not revealed.

At the end of May the horse was resection of the branch of the nerve. The result was negative - plantar flexion and lameness remained unchanged.
In September, the horse's husbandman turned to the specialists of the Department of Surgery. professor 1.O. Kalashnik KDZVA, which was assigned an additional $X$-ray from the dorsal and planktonic surface of the pharyngeal joint.

Additional $X$-ray findings have been found: epiphyseal, proximal, partially shifted to the tibia on the medial surface, and is composed of aseptic, diffuse periostitis with signs of detachment of the foam bone germ. In the inflammatory traumatic process, the tendons of the superficial and deep flexor and intercostal muscle are involved.

The results of clinical studies indicate a chronic course of the disease. The forecast is cautious.

All the above results of the research gave reason to pass that in this case the cause of the disease was the self-trauma of the right pelvis horse's limb. The results of our research and their conclusions were confirmed by experts from St. Petersburg and Berlin.

The horse was prescribed: a dose-wiring for 10 15 minutes twice a day, intramuscular administration to the zone of affected tissues of dexamethasone in a dose of $4 \mathrm{~m} /$ with a $0.5 \%$ solution of novocaine every other day and the use of dimethoxide-novocaine-ihtiol compress, daily for 15 days

At 35-40, signs of plantar flexion have almost disappeared. At this time, the horse is under the supervision of specialists in veterinary medicine, therapeutic measures are adjusted.

Key words: X-ray examination, horse, limb, bone marrow, flatulent joint 


\title{
РОЛЬ РЕНТГЕНОГРАФІЇ У ДІАГНОСТИЦІ ЗАХВОРЮВАНЬ ЛОКОМОТОРНОГО АПАРАТУ У КОНЯ (КЛінічнИй
}

\author{
А. В. Сарбаш, К. А. Синяговська \\ Харківська державна зооветеринарна академія, Харків, Україна \\ вул. Академічна, 1, смт. Мала Данилівка, Дергачівський район, Харківська обл., 62341; \\ E-mail: max milos@ukr.net
}

\begin{abstract}
У статті наведений кпінічний випадок встановлення діагнозу захворювання опорно-рухового апарату у коня за даними кпінічних, ультразвукових та рентгенологічних досліджень. Наведені дані свідчать, що здійснення рентгенограсрії $\varepsilon$ одним з ведучих діагностичних прийомів та повинна здійснюватися у двох проекціях (прямій та боковій), що значно підвищуе інформативність стану морфооструктури кісток.
\end{abstract}

Ключові слова: рентеенологічні дослідження, кінь, кінцівка, кістки плюсни, заплюсневий суелоб

\section{Вступ}

Актуальність теми: Локомоторний апарат у коней за своїм складом і механізмом дії є достатньо складним, а при його пошкодженні чи захворюванні діагностика потребує застосування різноманітних методів. Одним з основних клінічних ознак поряд 3 іншими (набряк, біль, гіперемія,) є кульгання, тобто порушення функції кінцівки (локомоторного апарату). Причиною кульгання можуть бути захворювання кісток, м'язів, суглобів, сухожильнозв'язувального апарату тощо. Для достовірної діагностики захворювань локомоторного апарату поряд 3 ретельним вивченням клінічних ознак необхідно застосовувати і спеціальні дослідження (рентгенографія, УЗД, блокаду окремих нервів), які виявляють та вказують на місце локалізації патологічного вогнища, а також морфоструктуру пошкоджених тканин.

Дуже часто захворювання локомоторного апарату у коней (розриви сухожилків, м'язів, вивихи суглобів, переломи кісток, запальні процеси в м'язах та сухожилках) $€$ причиною передвчасного вибраковування тварин. Хворі коні значно знижують свою працездатність та спортивні показники

Тому вважаємо, що діагностика захворювань кінцівок повинна бути своєчасною і комплексною та якомога інфоормативнішою.

Аналіз останніх досліджень і публікацій. За даними літератури в умовах кінно-спортивних шкіл кожен кінь хворіє в середньому 3-4 рази на рік, а коні, що зазнають значних навантажень під час тренінгу, - до 10 разів. Розглядання проблеми захворювань локомоторного апарату у коней висвітлені у працях відомих вчених (К.І. Шакалов, 1959; І.О. Поваженко, 1987; І.О. Калашник 1990 тощо). Вивчення питань патогенезу захворювань структур опорно-рухового апарату у тварин стосується сільськогосподарських тварин, а інформація щодо коней залишається мінімальною (Batrakov, \& Zaharov, 2000; Izdeps'kij, \& Zamazij, 2002; Procenko, \& SHeremet, 1990; Stoc'kij, \& Lazorenko, 2004; Rose, 1983).

Mema pоботи - на підставі застосування різних методів діагностики визначити діагноз у коня та призначити відповідні лікувальні заходи з метою відновлення функціональної діяльності локомоторного апарату.

Завдання дослідження: визначити інформативність ренттенографії при діагностиці захворювань локомоторного апарату у коня.
Матеріал та методи досліджень

Матеріалом для дослідження був жеребець темно-гнідої масті, віком 4 роки, за кличкою «Піонер». Для діагностики захворювань локомоторного апарату коня застосовували клінічні дослідження (огляд, пальпація, дослідження пасивними рухами, спеціальні дослідження у коней тощо), як у стані спокою, так й при проводці, по кругу хворою кінцівкою всередину. Даний вид діагностики здійснювали до та після проведення новокаїнової периневральної анестезії великогомілкового (n. tibialis) та глибокого малогомілкового (n. peronaeus profundus) нервів $з$ метою виключення больової чутливості, локалізованої в ділянці плюсни та скакального суглобу.

Також були проведені ультразвукові дослідження для встановлення стану сухожильнозв'язувального апарату, а також рентгенологічні дослідження всіх кісток та суглобів дистального відділу тазової кінцівки - копитного, вінцевого, путового, суглобів у стані опори кінцівки о ґрунт та стані флексії (Flexed Lat), а також рентген заплюсневого та колінного суглобів.

\section{Результати та їх обговорення}

За анамнестичними даними, кінь був придбаний наприкінці 2016 року. На той момент загальний стан його був в межах фізіологічних норм. Кінь був достатньо жвавий та рухливий, ознак кульгання не спостерігали. Утримували коня у конюшні в окремому деннику. Кожен день кінь був у тренінгу. За невідомих обставин приблизно через 2 місяці з дня придбання коня він почав несподівано кульгати на праву тазову кінцівку. Фахівцями ветеринарної медицини було проведено клінічні, рентгенологічні та ультразвукове дослідження, (рис.1.) на підставі яких було виявлено наявність морсоотруктурних пошкоджень сухожильнозв'язувального апарату у ділянці проксимальної частини плюснової кістки, а також запалення міжкісткового мускулу.

М'язова атрофрія кінцівки відсутня. При клінічному дослідженні травматичних пошкоджень на поверхні шкіри (удари, рани, набряки, крововиливи) виявлено не було.

Рентгенологічними дослідженнями фраланг пальців кінцівки та колінного суглобу вогнищ деструкції чи ущільнення кісток виявлено не було. Періостальна та ендостальні реакції відсутні. Суглобові щілини не звужені, їх деструкції не встановлено, структура кісток чітко візуалізується (рис. 2.) 


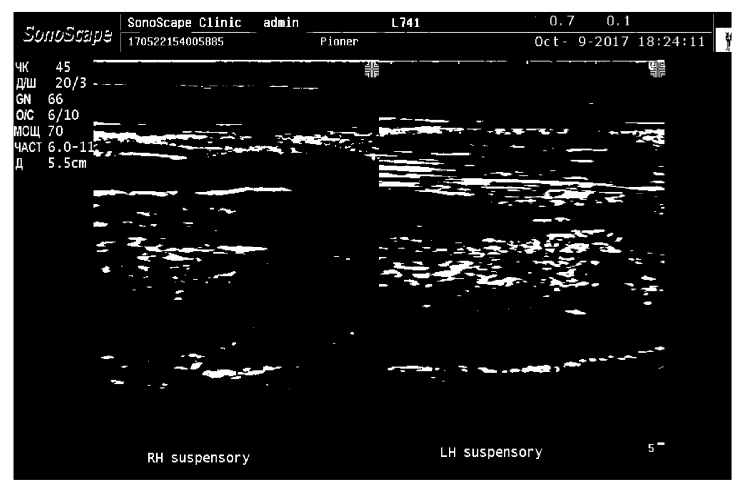

Рис. 1. Результати ультразвукового дослідження. Порушення структури сухожильно-зв'язувального апарату (зліва) у порівнянні зі здоровою кінцівкою (справа).

A

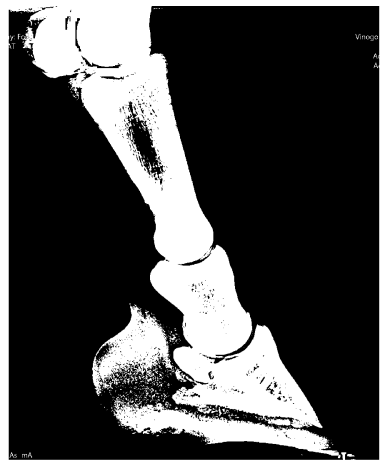

5

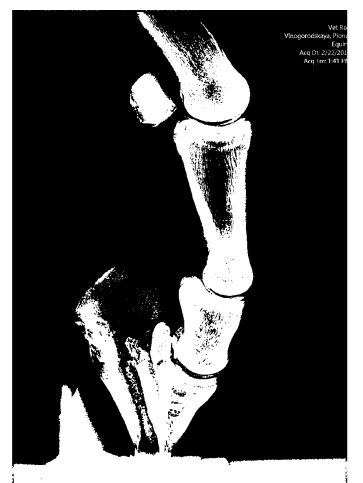

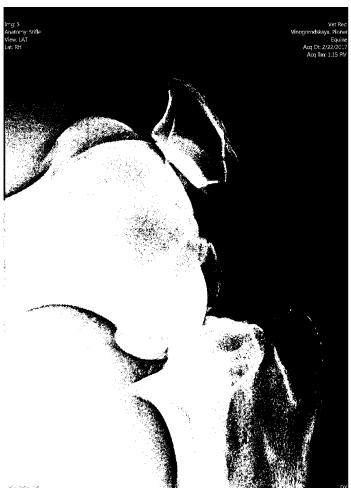

Рис. 2. Рентгенограма: A - кісток фалангів пальця у розігнутому стані; Б- у стані флексії;

В - колінного суглобу

Наприкінці травня 3 метою дослідження коня був залучений фахівець з Данії, який виявив параліч однієї з гілок малогомілкового нерву, і коню було здійснено резекцію ураженого нерву. Але результат був негативним- плантарна флексія та кульгання не змінилися. Після цього для постановки діагнозу було залучено двох англійських фахівців, які й визначили порушення морфоструктури сухожильнозв'язувального апарату.

У вересні господарка коня звернулася до фахівців кафедри хірургії ім. професора I.О. Калашника ХДЗВА з результатами усіх проведених досліджень та лікувальних заходів. Після їх вивчення та аналізу було призначено додаткову рентгенографрію з дорсальної та плантарної поверхні заплюсневого суглобу.

Аналіз додаткових рентгенографрічних досліджень проведених у різних проекціях по прояву світлих та темних тіней, а також структурних змін у кістках, виявив: епіфізарний, проксимальний, частково зрушений відлам плюснової кістки на медіальній поверхні та складнений асептичним, дифузним періоститом з ознаками відшарування окістя плюснової кістки. У запальний травматичний процес залучені сухожилки поверхневого та глибокого згинача пальця та міжкістковий мускул (рис 3.).

Результати клінічних досліджень вказують на хронічний перебіг даного захворювання. Прогноз обережний.

Всі вищевикладені результати досліджень дали підставу перепустити, що в даному випадку причиною розвитку захворювання було самотравмування правої тазової кінцівки коня. Результати наших досліджень та їх висновки було підтверджено фрахівцями із Санкт-Петербургу та Берліну.

Відповідно до встановленого діагнозу (3 урахуванням клінічної форми прояву ознак та перебігу хвороби) коню було призначено наступні лікувальні заходи: дозована проводка по 10-15 хвилин два рази на день, внутрішньом'язові введення у зону уражених тканин дексаметазону в дозі 4 мл з 0,5 \% розчином новокаїну через день та застосування димексид-новокаїн-іхтіолового компресу, щоденно протягом 15 днів. 
A

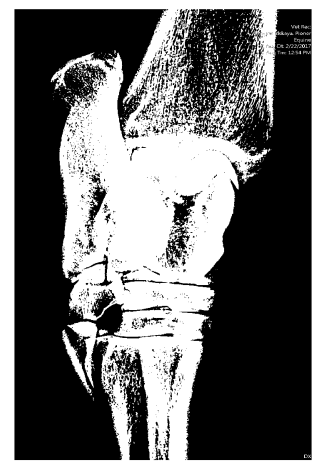

Рис. 3. Рентгенограма хворої кінцівки:

А - Під час первинного дослідження. Проекція знімку не дозволяє встановити наявність морфоструктурних змін кістки. Б - Після здійснення додаткової рентгенографії. Добре виражені відлом та вогнища запалення окістя плюсневої кістки.

Лікувальні заходи корегувалися 3 урахуванням клінічних показників та перебігу. На 3540 добу ознаки плантарної флексії майже зникли. На цей час кінь знаходиться під наглядом фахівців ветеринарної медицини.

\section{Висновки}

1. Результати досліджень свідчать, що діагностика захворювань локомоторного апарату у коней $\epsilon$ достатньо складною і потребує різних ретельних, як клінічних, так й спеціальних методів досліджень.
2. Достовірна діагностика захворювання кінцівки коня, у даному випадку, була досягнена завдяки проведенню рентгенографрії в двох проекціях, що дозволило виявити періостальну реакцію і відлам кістки.

3. Лікування коней 3 травматичними пошкодженнями локомоторного апарату 3 урахуванням їх клінічних форм прояву, анатомофрізіологічної будови та фрункції повинні здійснюватися згідно достовірного діагнозу.

\title{
References
}

Batrakov, A. JA., \& Zaharov, P. G. (2000). Prichiny boleznej sustavov u krupnogo rogatogo skota. Veterinarija, 2, 10-15 (in Russian)

Izdeps'kij, V. J., \& Zamazij, A. A. (2002). Dejaki pitannja patogenezu ta patogenetichni metodi likuvannja aseptichnih artritiv u konej. Nauk. praci Poltav. derzh. agrar. akad. Veterinarni nauki, 2(21), 318-321 (in Ukrainian).

Procenko, A. A. \& SHeremet, S. I. (1990). Lechenie asepticheskih vospalitel'nyh processov oporno-dvigatel'nogo apparata u sportivnyh loshadej. Sovershenstvovanie hozjajstvennogo mehanizma i intensifikacija agropromyshlennogo proizvodstva, 2, 178-180 (in Russian).

Stoc'kij, O. G., \& Lazorenko, A. B. (2004). Rozpovsjudzhennja ta struktura hirurgichnoï patologiï u konej. Visnik Poltav. derzh. agrar. Akad., 1, 17-20 (in Ukrainian).

Rose, R. J. (1983). The diagnosis and treatment of arthritis in horses. Veterinary Journal, 31(1-2), 13-15.

\section{THE METHODS OF CRYOPRESERVATION OF RED BLOOD CELLS OF ANIMAL}

\author{
O. M. Denysova, T. I. Yakymenko, B. B. Vashenko, G. P. Zhegunov, V. O. Prichodchenko, N. I. Gladka \\ Kharkiv State Zooveterinary Academy, Kharkiv, Ukraine \\ Academichna str., 1, Mala Danylivka, Dergachi district, Kharkiv region, 62341 \\ E-mail:denisova78@yahoo.com
}

Nowadays, the method of blood transfusion is often used in veterinary practice. Hypothermic storage allows to save blood cells for a limited time, while morphofunctional parameters are getting worse. Cryopreservation allows to save and receive highquality cells for the use in veterinary practice. Therefore, the development of reserves of donor blood is possible with long-term preservation in the frozen state. The use of cryopreservation makes it possible to avoid a number of problems: finding a donor at the right time for transfusion, the cost of maintaining the donor, etc. These days high therapeutic efficacy of using cryopreserved red blood cells was confirmed in intensive therapy and hematological diseases.

The survival of biological objects under cryopreservation conditions is due to the ability of cells to withstand a complex of negative factors, including: the formation of crystals, an increase in the concentration of salts and osmotic pressure, dehydration of macromolecules and phase transitions of membrane lipids. Fundamental studies of physicochemical processes in cell suspensions under cooling and freezing conditions revealed important patterns that determine the basic principles of damage 